\title{
Biodegradation of pyrene and catabolic genes in contaminated soils cultivated with Lolium multiflorum $\mathbf{L}$
}

\author{
Sardar Khan • Abd El-Latif Hesham • Gu Qing • \\ Liu Shuang • Jizheng He
}

Received: 23 October 2008 / Accepted: 5 December 2008 / Published online: 18 February 2009

(C) Springer-Verlag 2009

\begin{abstract}
Background, aim, and scope In the soil environment, polycyclic aromatic hydrocarbons (PAHs) and heavy metals (HMs) are of great environmental and human health concerns due to their widespread occurrence, persistence, and carcinogenic properties. Bioremediation of contaminated soil is a cost-effective, environmentally friendly, and publicly acceptable approach to address the removal of environmental contaminants. However, bioremediation of contaminants depends on plant-microbe interactions in the rhizosphere. The microorganisms that can mineralize various PAHs have PAH dioxygenase genes like nahAc, phnAc, and pdol. To understand the fate of pyrene in rhizospheric and non-rhizospheric soils in the presence or absence of $\mathrm{Pb}$, pyrene biodegradation, bacterial community structure, and dioxygenase genes were investigated in a pot experiment.

Methods Soil was amended with $\mathrm{Pb}$ (a representative heavy metal), pyrene, and a $\mathrm{Pb} /$ pyrene mixture. After 8 weeks of aging, one set of pot microcosms was cultivated with rye grass (Lolium multiflorum L) seedlings, while another set was not cultivated for the purpose of comparing rhizosphere and non-rhizosphere pyrene degradation. Pyrene
\end{abstract}

S. Khan $(\bowtie)$

Department of Environmental Sciences, University of Peshawar,

25120 Peshawar, Pakistan

e-mail: sardar.khan2008@yahoo.com

G. Qing $\cdot$ L. Shuang · J. He

Research Center for Eco-Environmental Sciences,

Chinese Academy of Sciences,

Beijing 100085, China

A. El-Latif Hesham

Genetics Department, Faculty of Agriculture, Assiut University,

Assiut, Egypt was extracted from freeze-dried soil and plant samples using a Soxhlet extraction method and the extracts were dried to $1 \mathrm{~mL}$ under gentle nitrogen flow and analyzed using gas chromatograph mass spectrometry (Agilent 6890, USA). Soil DNA was extracted from triplicate samples and the DGGE was performed using a Bio-Rad Dcode ${ }^{\mathrm{TM}}$ Universal Mutation Detection System (Bio-Rad, USA). PAH dioxygenase genes, including nahAc, phnAc, and pdo1, were detected using PCR amplification. Similarly, pyrene degraders were also investigated using plate counting technique.

Results Biodegradation rates recorded over an 18 -week period showed that rye grass promoted significant $(P<0.05)$ pyrene degradation. Pyrene removal efficiency from rhizospheric soils was $59.1 \pm 2.1 \%$ and $68.7 \pm 2.3 \%$ in pyreneand $\mathrm{Pb} /$ pyrene-amended soils, respectively. The results indicate that pyrene dissipation was significantly $(P<0.05)$ higher in $\mathrm{Pb} /$ pyrene-amended soils than only-pyreneamended soils. The plant growth promoted the degradation of pyrene and accounted for $12.1 \%$ to $17.0 \%$ of dissipation enhancement in the rhizospheric soils. In this study, the DGGE profiles revealed a shift in soil bacterial community structure in all amended soils, with a higher number and greater complexity of banding patterns in $\mathrm{Pb} /$ pyreneamended samples than in either $\mathrm{Pb}$ - or pyrene-amended samples. In the control and $\mathrm{Pb}$-amended soil, pdol and $n a h A c$ genes were not detected throughout the incubation period but were detected in the pyrene- and $\mathrm{Pb}$ /pyreneamended soils. However, phnAc genes were not detected in either amended or non-amended soils throughout the incubation period. The addition of pyrene had a dramatic effect on the number of pyrene degraders.

Discussion Plants contribute to the degradation of PAHs by increasing the size of microbial population, promoting microbial activity, and modifying microbial community 
diversity in the rhizosphere. In this study, the presence of plants significantly promoted the degradation of pyrene in the soil due to enhanced bacterial community size and increased the number of pyrene degraders. Similarly, the results of this study have also clearly shown that pyrene remaining in soils only accounted for about $1 / 3$ of the total pyrene addition, suggesting that most of the pyrene added could be removed by plant and/or microbial degradation. HMs and PAHs interaction towards degradation of PAHs can be both negative and positive depending on type and concentration of both HMs and PAHs. In both rhizospheric and non-rhizospheric soils, the pyrene degradation was in line with the changes of bacterial structure, increasing number of pyrene degraders, and the prevalence of dioxygenase genes (nahAc and pdol). This work represents the first report that $\mathrm{Pb}$ can affect the dissipation of pyrene and functional genes were detected in both rhizospheric and non-rhizospheric soils amended with pyrene and $\mathrm{Pb} /$ pyrene. Conclusions Pyrene removal efficiency for rhizospheric soils was higher than for non-rhizospheric soils and pyrene dissipation was accelerated in the presence of $\mathrm{Pb}$ in both rhizospheric and non-rhizospheric soils. The bacterial community structure was changed and the addition of pyrene indicated dramatic effects on the number of pyrene degraders. The catabolic genes, including $n a h A c$ and pdol, which are responsible for HMW-PAH degradation, were confirmed in both rhizosphere and non-rhizosphere soils amended with pyrene or $\mathrm{Pb} /$ pyrene.

Recommendations and perspectives Our findings suggest that the interaction between bacterial community and plant roots could influence the PAH degradation both in the presence and absence of HMs in the contaminated soils.

Keywords Bacterial community · Dioxygenase genes .

Non-rhizosphere $\cdot \mathrm{Pb}$-contaminated soil $\cdot$ Pyrene

degradation $\cdot$ Rhizosphere $\cdot$ Rye grass

\section{Background, aim, and scope}

Mixtures of polycyclic aromatic hydrocarbons (PAHs) and heavy metals (HMs) are becoming increasingly prevalent in soil environments as a result of anthropogenic and natural activities (Khan et al. 2008a; Tang et al. 2005; Macleod and Semple 2006). The effect and fate of PAHs in these environments are of great environmental and human health concern due to their widespread occurrence, persistence, and carcinogenic properties. Numerous studies have been conducted on remediation of the soil contaminated with PAHs and HMs using different approaches (Arthur et al. 2005; Yoon et al. 2006; Wu et al. 2008). However, bioremediation (the use of plants and/or microbes to remediate contaminated soil) seems to be an attractive and promising approach because it is a cost-effective, noninvasive, and publicly acceptable way to address the removal of environmental contaminants (Chadhain et al. 2006). The presence of plants can have various effects on soil contaminants, and vegetated soils are capable of more effectively removing PAHs and HMs (US-EPA 2000). Plant processes that promote the removal of contaminants from soil are either direct or indirect. Direct processes include plant uptake into roots or shoots and transformation, storage, or transpiration of the contaminants, while indirect plant processes involve the degradation of contaminants by microbes in the rhizosphere (Hutchinson et al. 2003).

Bioremediation of contaminants depends on plantmicrobe interactions in the rhizosphere, but the extent and intensity of such rhizosphere effects are likely to decrease with increasing distance from the root surface (Joner and Leyval 2003; Su and Zhu 2007). In the past, numerous studies have reached the conclusion that microbial degradation of PAHs is enhanced in the rhizosphere (Rentz et al. 2004). Nevertheless, the basic mechanisms involved remain poorly understood, and there still exists a lack of information on the contribution of plants and microbes to the removal of soil PAHs. The presence and distribution of microorganisms that can degrade PAHs in soils have been well documented (Kim et al. 2006; Hamamura et al. 2006). Although numerous studies have been conducted on bacterial community structure associated with bioremediation of soil PAHs (Kaplan and Kitts 2004), little is known about bioremediation of high molecular weight (HMW) PAHs and microbial population dynamics throughout the biodegradation process.

To make advances in microbial remediation technologies, we need an understanding of the underlying principles of microbial PAH metabolism. The bacteria that can mineralize various PAHs, including naphthalene, anthracene, fluoranthene, pyrene, phenanthrene, benzo $[a]$ pyrene, and benz $[a]$ anthracene, have aromatic-ring hydroxylating dioxygenase enzymes that introduce two atoms of oxygen into PAHs to form a cis-dihydrodiol (Kim et al. 2006). The best-studied PAH dioxygenases are nahAc, phnAc, and pdo1 isolated from Pseudomonas putida OUS82 (Baldwin et al. 2003), Burkholderia sp. RP007 (Laurie and LloydJones 1999), and Mycobacterium sp. 6PY1 (Krivobok et al. 2003), respectively. These genes have been found in a wide variety of bacteria and geographic locations (Lloyd-Jones et al. 1999; Widada et al. 2002; Johnsen et al. 2006).

Most studies have concentrated on bioremediation of a single contaminant, as mentioned above. In the real environment, contaminated soils usually contain mixtures of chemicals rather than a single substance. Numerous investigations have been only devoted to the combined effect of PAHs and HMs on soil microbial activity (Shen et al. 2006), but not to bioremediation of PAH-contaminated 
soils containing HMs. However, this area of research has not been covered to any extent and needs further extensive studies. The present study was conducted to investigate the bioremediation of pyrene- and $\mathrm{Pb} /$ pyrene-contaminated rhizospheric and non-rhizospheric soils cultivated with rye grass (Lolium multiflorum L). Polymerase chain reaction (PCR)-denaturing gradient gel electrophoresis (DGGE) was used to assess changes in the bacterial community structure in both rhizospheric and non-rhizospheric soils during incubation. Bacterial PAH dioxygenase genes including $n a h A c, p h n A c$, and pdol were also investigated.

\section{Materials and methods}

\subsection{Chemicals}

Pyrene was purchased from Chem Service Inc. (West Chester, PA, USA). All solvents purchased from Beijing Chemical Factory (Beijing, China) were of analytical grade and redistilled in an all-glass system before use. Silica gel, alumina $\left(\mathrm{Al}_{2} \mathrm{O}_{3}\right)$, and sodium sulfate $\left(\mathrm{Na}_{2} \mathrm{SO}_{4}\right)$ were purchased from Qingdao Haiyang Chemical Co. (Shangdong, China).

\subsection{Soil}

Fresh field soil $(0-20 \mathrm{~cm})$ with an unknown history of petroleum or industrial contamination was obtained from Beijing, China. The soil was classified as Endoaquepts in the USA Soil Taxonomy. The soil was air-dried and passed through a $<2-\mathrm{mm}$ sieve. The soil particle size composition was $42.5 \%$ sand, $46.1 \%$ silt, and $11.4 \%$ clay. The soil $\mathrm{pH}$ was 8.0 as measured in $\mathrm{H}_{2} \mathrm{O}$ (1:2.5 ratio), soil organic matter was $1.7 \%$, and total $\mathrm{Pb}$ concentration was $2.60 \mathrm{mg} \mathrm{kg}$. The initial level of pyrene in the soil was below the detection limit.

\subsection{Experimental design}

For the contamination process, pyrene was dissolved in acetone $(5 \mathrm{~mL})$ and sprayed on a portion of the soil $(2 \mathrm{~kg}$ out of $6 \mathrm{~kg}$ ). The acetone was allowed to evaporate in a fume hood and then properly mixed with the remaining soils. Similarly, lead nitrate $\left(\mathrm{Pb}\left(\mathrm{NO}_{3}\right)_{2}\right)$ solution was used for $\mathrm{Pb}$ contamination and soil was properly homogenized by hand after drying. Exactly $1 \mathrm{~kg}$ of soil was used to fill each pot microcosm and made with the following amendments: (1) control (no $\mathrm{Pb}$ and pyrene), (2) amended with $\mathrm{Pb}\left(300 \mathrm{mg} \mathrm{kg}^{-1}\right)$, (3) amended with pyrene $\left(30 \mathrm{mg} \mathrm{kg}^{-1}\right)$, and (4) amended with both $\mathrm{Pb} /$ pyrene $\left(300 / 30 \mathrm{mg} \mathrm{kg}^{-1}\right)$. Each amendment was performed in triplicate. Soil for the control and $\mathrm{Pb}$ amendments was also spiked with the same amount of acetone to balance effects on soil microorganisms for comparison with other amendments (Brinch et al. 2002). It is well known that organic and inorganic pollutants can become sequestered into the soil matrix (Hatzinger and Alexander 1995), which is referred to as the aging process. For aging purposes, the pot microcosms were sealed in dark polyethylene bags and incubated in the greenhouse for 8 weeks at $25 \pm 3^{\circ} \mathrm{C}$, and field soil moisture contents $(70 \%)$ were adjusted by adding deionized water at regular intervals.

After the aging process, the microcosms were divided into two sets, one set was cultivated with rye grass seedlings (Lolium multiflorum L.) while another set was not cultivated. Rye grass seedlings were prepared using the method of Khan et al. (2006), and each amendment was provided in triplicate. After the seedlings were transplanted, this pot microcosm experiment was continued for 10 weeks in the greenhouse with day temperature of $27 \pm 4^{\circ} \mathrm{C}$ and night temperature of about $20 \pm 3^{\circ} \mathrm{C}$ and relative humidity of $67 \pm 2 \%$. In this study, sterile controls were not included to assess the amount of pyrene lost due to abiotic processes because, in most of the previous work, abiotic pyrene degradation accounted for less than $0.05 \%$ over a 60 -day period (Jouanneau et al. 2005).

\subsection{Soil sampling from pots}

After $5 \mathrm{~h}$ of soil contamination, $\sim 12$-g samples were collected from all amended soils to investigate the initial soil contaminant concentrations. All the soil from the vegetated pots were considered as rhizospheric soils (because rye grass plants have a dense fibrous root system and fill the whole microcosm's soil), and non-vegetated pots act as non-rhizospheric soils. Sub-samples of soil ( $\sim 15 \mathrm{~g})$ were collected at $2,4,6,8$, and 18 weeks from each microcosm, freeze-dried, homogenized with a pestle, and stored at $-20^{\circ} \mathrm{C}$ for further analyses.

\subsection{Pyrene extraction and analysis}

Pyrene was extracted from freeze-dried soil and plant samples using a Soxhlet extraction method with $200 \mathrm{~mL}$ dichloromethane (DCM) for $24-\mathrm{h}$ at $60^{\circ} \mathrm{C}$. After filtration, the extract was evaporated to $1 \mathrm{~mL}$ under reduced pressure at $35^{\circ} \mathrm{C}$ using a rotary evaporator. Silica chromatography columns were prepared with silica gel, $\mathrm{Al}_{2} \mathrm{O}_{3}$, and capped with $\mathrm{Na}_{2} \mathrm{SO}_{4}$; after this, the columns were washed with hexane. The concentrated extracts were then loaded to columns to separate the pyrene from other polar interfering compounds. These columns were eluted with hexane and DCM (7:3); the eluted fractions were again evaporated up to $1 \mathrm{~mL}$ using a rotary evaporator and transferred to a Kuderna-Danish concentrator and rinsed with $10 \mathrm{~mL}$ of 
$n$-hexane. The extracts were dried to $1 \mathrm{~mL}$ under gentle nitrogen flow and analyzed using gas chromatograph mass spectrometry (GC-MS, Agilent 6890, USA). The GC-MS conditions were the same as those used in our previous study (Khan et al. 2008b) and chromatographic data were collected and processed using GC-MS Chemstation software.

\subsection{Microbiological analyses}

\subsubsection{DNA extraction and PCR amplification}

Total community DNA was extracted from triplicate samples of $0.5 \mathrm{~g}$ of fresh soil by a bead-beating procedure using the Fast DNA Spin Kit (for soil) as described by the manufacturer (Bio 101 Inc., USA). Yield and quality of the extracted DNA was verified by $1.0 \%$ agarose gel electrophoresis and stained with ethidium bromide. The region corresponding to nucleotide positions 341 and 500 in the 16S rRNA of Escherichia coli was PCR-amplified using the primers described by Muyzer et al. (1993), as shown in Table 1. PCR amplification was performed on an iCycler Thermal Cycler (Bio-Rad, USA) in $50-\mu \mathrm{L}$ reaction volumes. A touch down temperature profile was adopted in which the annealing temperature was reduced from $65^{\circ} \mathrm{C}$ by $0.5^{\circ} \mathrm{C}$ on successive cycles until the theoretical annealing temperature of $55^{\circ} \mathrm{C}$ was reached after 20 cycles; a further 10 cycles were performed at this temperature. The PCR reaction mixture, with a final volume of $50 \mu \mathrm{L}$, contained $15 \mathrm{pmol}$ of each primer, $200 \mu \mathrm{mol}$ of each deoxyribonucleoside triphosphate, $5 \mu \mathrm{L}$ of $10 \times \mathrm{PCR}$ buffer, $3 \mu \mathrm{L}$ of magnesium chloride $\left(\mathrm{MgCl}_{2}\right)\left(25 \mathrm{mmol} \mathrm{L}{ }^{-1}\right)$, 1.25 unit $\mu \mathrm{L}^{-1}$ Taq polymerase, and $1-10 \mathrm{ng}$ of the DNA extracts as a template.

\subsubsection{Denaturing gradient gel electrophoresis}

The DGGE was performed using a Bio-Rad Dcode ${ }^{\mathrm{TM}}$ Universal Mutation Detection System (Bio-Rad, USA). The PCR products were loaded on $0.8-\mathrm{mm}$-thick polyacrylamide gel $(10 \% \mathrm{w} / v$ acrylamide to bisacrylamide, $37.5: 1)$ using a denaturing gradient from $30 \%$ to $50 \%$ of urea and formamide $\left(100 \%\right.$ corresponds to $7 \mathrm{~mol} \mathrm{~L}^{-1}$ urea and $40 \%$ $w / v$ formamide) being increased in the direction of the electrophoresis run. The electrophoresis was run for $6 \mathrm{~h}$ under a constant voltage of $120 \mathrm{~V}$ and a constant temperature of $60^{\circ} \mathrm{C}$. After the run, the gels were stained for $20 \mathrm{~min}$ in $1 \times \mathrm{TAE}$ containing $0.5 \mathrm{mg} \mathrm{mL}^{-1}$ ethidium bromide and rinsed with distilled water, then photographed using gel Doc 1000 (Bio Rad, USA).

\subsubsection{Detection of dioxygenase genes}

PCR amplifications for detection of the classical PAH dioxygenase genes including nahAc, phnAc, and pdol were performed using the primers as described in Table 1. All PCR amplifications were performed on an iCycler Thermal Cycler (Bio-Rad, USA) in $50-\mu \mathrm{L}$ reaction volumes, as described by Johnsen et al. (2006). Briefly, the nahAc, phnAc, and pdol PCRs were performed with $1.0 \mu \mathrm{M}$ primer, $2.5 \mathrm{mM} \mathrm{MgCl}$, and $1 \mu \mathrm{L}$ of soil DNA. PCR for nahAc $\left(5 \mathrm{~min}\right.$ at $94^{\circ} \mathrm{C} ; 40$ cycles of $30 \mathrm{~s}$ at $94^{\circ} \mathrm{C}, 30 \mathrm{~s}$ at $57^{\circ} \mathrm{C}, 30 \mathrm{~s}$ at $72^{\circ} \mathrm{C} ; 6 \mathrm{~min}$ at $\left.72^{\circ} \mathrm{C}\right)$, for phnAc $(5 \mathrm{~min}$ at $94^{\circ} \mathrm{C} ; 40$ cycles of $30 \mathrm{~s}$ at $94^{\circ} \mathrm{C}, 30 \mathrm{~s}$ at $59^{\circ} \mathrm{C}, 1 \mathrm{~min}$ at $72^{\circ} \mathrm{C}$; $6 \mathrm{~min}$ at $\left.72^{\circ} \mathrm{C}\right)$, and for $p d o 1\left(5 \mathrm{~min}\right.$ at $94^{\circ} \mathrm{C} ; 40$ cycles of $30 \mathrm{~s}$ at $94^{\circ} \mathrm{C}, 30 \mathrm{~s}$ at $56^{\circ} \mathrm{C}, 1 \mathrm{~min}$ at $72^{\circ} \mathrm{C} ; 6 \mathrm{~min}$ at $72^{\circ} \mathrm{C}$ ) were optimized. The presence of the dioxygenase genes was evaluated by agarose (1.0\%) gel electrophoresis, followed by image analysis using a gel Doc 1000 (Bio$\mathrm{Rad})$. The amplified fragments of the PCRs were $992 \mathrm{bp}$ (nahAc), 993 bp (phnAc), and 793 bp (pdol). In all PCR reactions, negative controls were included to verify possible contamination.

\subsubsection{Pyrene degraders}

From each microcosm, $10.0 \mathrm{~g}$ of soil was weighed into 300-mL Erlenmeyer flasks containing $90 \mathrm{~mL}$ of sterile pyrophosphate buffer $\left(\mathrm{Na}_{4} \mathrm{P}_{2} \mathrm{O}_{7} \cdot 10 \mathrm{H}_{2} \mathrm{O}, 2 \mathrm{mM}, \mathrm{pH} 7.0\right)$ and shaken for $15 \mathrm{~min}$ at $250 \mathrm{rpm}$ (Johnsen et al. 2006). From each soil extract, 100-fold dilutions were prepared in test

Table 1 List of primers used for characterizing the bacterial community structure and dioxygenase genes (nahAc, phnAc, and pdol)

\begin{tabular}{|c|c|c|c|c|}
\hline Primers & Sequence $\left(5^{\prime}-3^{\prime}\right)$ & Target & Size (bp) & Reference \\
\hline $\begin{array}{l}\text { EU341-F } \\
\text { EU500-R }\end{array}$ & $\begin{array}{l}\text { CCTACGGGAGGCAGCAG } \\
\text { AGAGTTTGATC(A/C)TGGCTCAG }\end{array}$ & 16S rRNA & 200 & Muyzer et al. (1993) \\
\hline $\begin{array}{l}\text { nahAc-F } \\
\text { nahAc-R }\end{array}$ & $\begin{array}{l}\text { TGGCGATGAAGAACTTTTCC } \\
\text { AACGTACGCTGAACCGAGTC }\end{array}$ & $n a h A c$ & 992 & Laurie and Lloyd-Jones (2000) \\
\hline $\begin{array}{l}\text { phnAc8073-F } \\
\text { phnAc9047-R }\end{array}$ & $\begin{array}{l}\text { TTCGAGCTGGAATGTGAGC } \\
\text { AATAACCGGCGATTCCAAAC }\end{array}$ & phnAc & 993 & Laurie and Lloyd-Jones (1999) \\
\hline $\begin{array}{l}\text { pdo1-F } \\
\text { pdo1-R }\end{array}$ & $\begin{array}{l}\text { GTT CTA CCT CGA CCT CAT TGC } \\
\text { CTG ACC CAT GTA TTC CAG CC }\end{array}$ & pdol & 793 & Krivobok et al. (2003), Johnsen et al. (2006) \\
\hline
\end{tabular}


tubes containing $9 \mathrm{~mL}$ of the pyrophosphate buffer. Three replicates of $100 \mu \mathrm{L}$ from each soil dilution were plated and spread onto a basal salt medium containing mineral nutrients but no carbon source. The basal salts medium contained di-potassium hydrogen phosphate trihydrate $\left(\mathrm{K}_{2} \mathrm{HPO}_{4} \cdot 3 \mathrm{H}_{2} \mathrm{O}\right)\left(4.25 \mathrm{gL}^{-1}\right)$, monosodium dihydrogen phosphate trihydrate $\left(\mathrm{NaH}_{2} \mathrm{PO}_{4} \cdot 3 \mathrm{H}_{2} \mathrm{O}\right)\left(1.0 \mathrm{gL}^{-1}\right)$, ammonium chloride $\left(\mathrm{NH}_{4} \mathrm{Cl}\right)\left(2.0 \mathrm{gL}^{-1}\right)$, magnesium sulfate heptahydrate $\left(\mathrm{MgSO}_{4} \cdot 7 \mathrm{H}_{2} \mathrm{O}\right)\left(0.2 \mathrm{gL}^{-1}\right)$, ferrous sulfate heptahydrate $\left(\mathrm{FeSO}_{4} \cdot 7 \mathrm{H}_{2} \mathrm{O}\right)\left(0.012 \mathrm{gL}^{-1}\right)$, magnesium sulfate heptahydrate $\left(\mathrm{MnSO}_{4} \cdot 7 \mathrm{H}_{2} \mathrm{O}\right)\left(0.003 \mathrm{gL}^{-1}\right)$, zinc sulfate heptahydrate $\left(\mathrm{ZnSO}_{4} \cdot 7 \mathrm{H}_{2} \mathrm{O}\right)\left(0.003 \mathrm{gL}^{-1}\right)$, and cobalt sulfate heptahydrate $\left(\mathrm{CoSO}_{4} \cdot 7 \mathrm{H}_{2} \mathrm{O}\right)\left(0.001 \mathrm{gL}^{-1}\right)$. The plates were coated with a solution of pyrene in hexane/ acetone (1:1) until an opaque layer had formed on the surface. Controls with and without pyrene were also included to check any possible contamination. The inoculated plates were placed in an incubator at $30^{\circ} \mathrm{C}$ for 3 to 4 weeks to form visible colonies, and the colonies were measured as the most probable number (MPN) (Stapleton et al. 1998).

\subsection{Recovery and quality control}

In order to check the quality and recovery of pyrene, subsamples of clean soil were spiked with a known pyrene concentration $\left(2 \mu \mathrm{g} \mathrm{g}^{-1}\right)$. The recovery and reproducibility of the extraction method was satisfactory $(92.5 \pm 5.3 \%)$.

\subsection{Data analysis}

The figures presented are the mean values and standard errors of triplicates. All results were statistically analyzed using the SPSS 11.5 computer package. The means were compared using Duncan test and pair-samples $T$-test, with a significance level of $P<0.05$.

\section{Results}

\subsection{Potential degradation of pyrene}

Pyrene degradation in rhizospheric and non-rhizospheric soils is given in Fig. 1. The data indicate that pyrene was significantly $(P<0.05)$ removed, although different samples demonstrated different degradation patterns. Pyrene degradation extent ranged from $1.9 \pm 0.7 \%$ to $13.65 \pm 1.6 \%$ in pyrene-amended samples and from $2.3 \pm 0.9 \%$ to $19.57 \pm$ $1.9 \%$ in $\mathrm{Pb} /$ pyrene-amended samples, after an 8 -week incubation period. Pyrene degradation extent for rhizospheric soils was $59.1 \pm 2.1 \%$ (pyrene-amended samples) and $68.7 \pm 2.3 \%$ (Pb/pyrene-amended samples), after an 18 -week period. Similarly, pyrene removal extent for

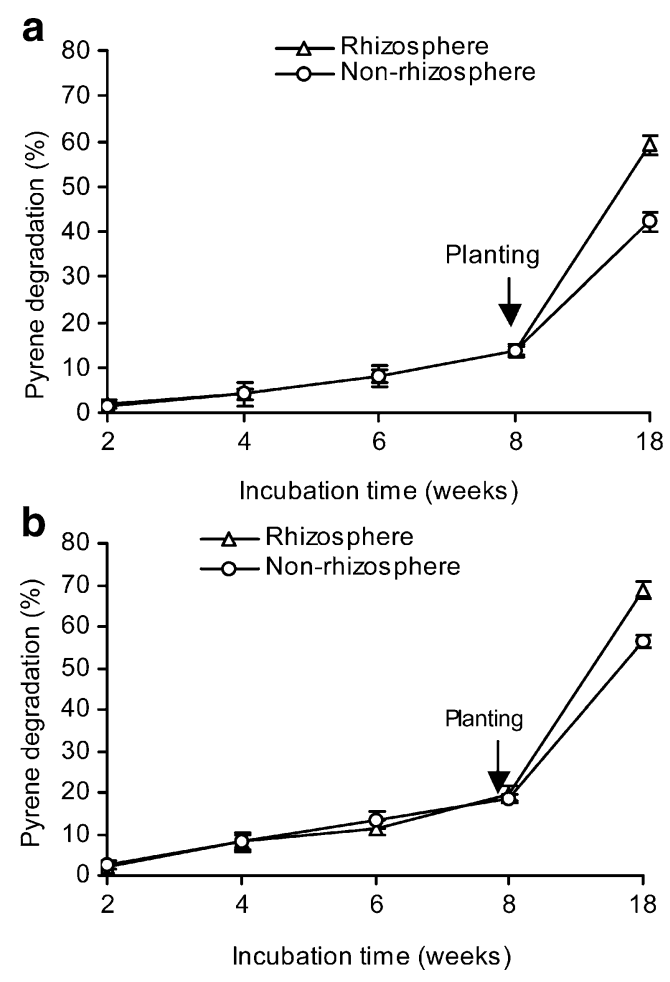

Fig. 1 Pyrene degradation (\%) in rye-grass rhizospheric and nonrhizospheric soils contaminated with (a) pyrene and (b) $\mathrm{Pb}$ /pyrene mix (divided into rhizospheric and non-rhizospheric soils after 8 weeks)

non-rhizospheric soils was $42.1 \pm 1.9 \%$ (pyrene-amended samples) and $56.6 \pm 1.5 \%(\mathrm{~Pb} /$ pyrene-amended samples), after an 18-week period (see Fig. 1). The results indicate that pyrene dissipation was significantly $(P<0.05)$ higher in $\mathrm{Pb}$ /pyrene-amended soils than in only-pyrene-amended soils. At the end of the experiment, the extractable concentrations of pyrene in the rhizospheric soils, ranging from 11.16 to $12.34 \mathrm{mg} \mathrm{kg}^{-1}$, were significantly lower than in the non-rhizospheric soils, ranging from 13.34 to $17.47 \mathrm{mg} \mathrm{kg}^{-1}$. The data indicated that plant growth promoted the degradation of pyrene and accounted for $12.1 \%$ to $17.0 \%$ of dissipation enhancement in the rhizospheric soils.

\subsection{DGGE for bacterial community structure}

DGGE profiles of 16S rRNA gene fragments of soils collected from all samples at time $0,4,8$, and 18 weeks during the incubation from both rhizospheric and nonrhizospheric soils are given in Fig. 2. In this study, the DGGE profiles revealed a shift in soil bacterial community structure in all amended soils, with a higher number and greater complexity of banding patterns in $\mathrm{Pb}$ /pyreneamended samples than in either $\mathrm{Pb}$ - or pyrene-amended samples. Similarly, the DGGE profiles also indicated a change in bacterial community structure in rhizospheric 
Fig. 2 DGGE banding patterns (a) and their similarity dendrograms/ cluster analysis (b) of

16S r RNA gene fragments from soil samples amended with $\mathrm{Pb}$, pyrene (Py), and $\mathrm{Pb}$ plus pyrene $(\mathrm{Pb} /$ py) during different incubation periods; $\mathrm{ck}^{*}$ and $\mathrm{ck}^{* *}$ represent initial control (0 time) and final control (18-week), respectively while ${ }^{a}$ non-rhizospheric and ${ }^{\mathrm{b}}$ rhizospheric soils

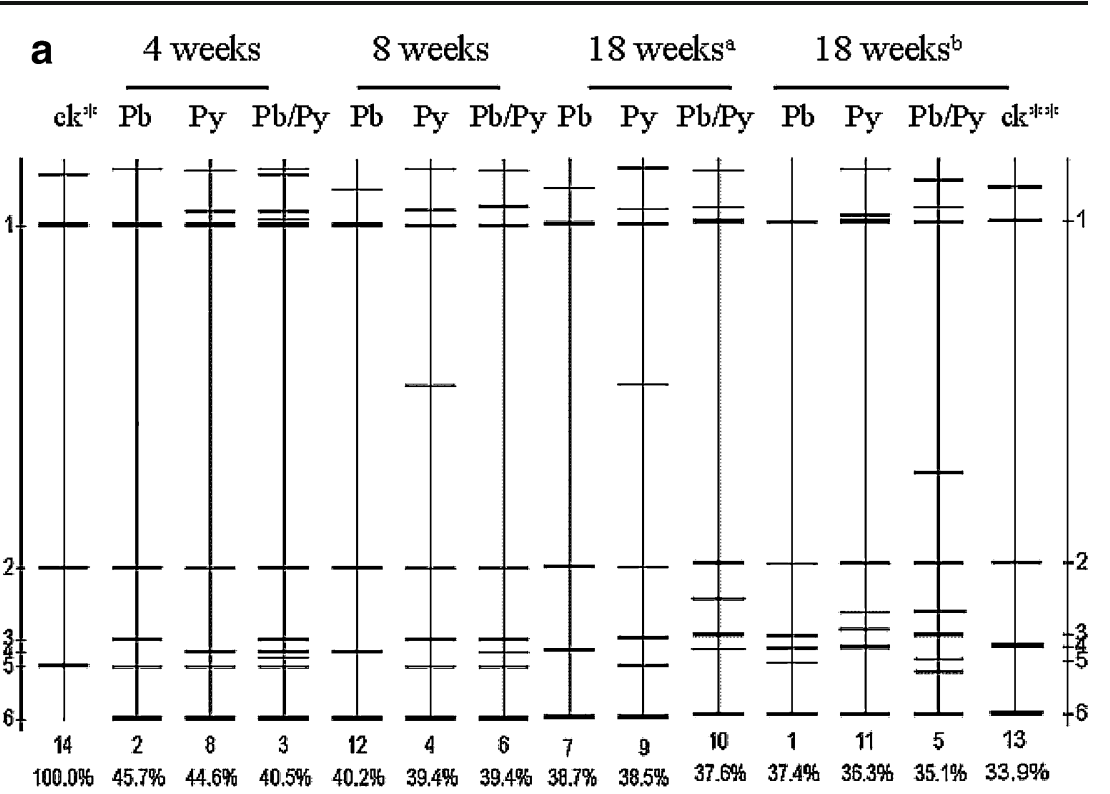

b

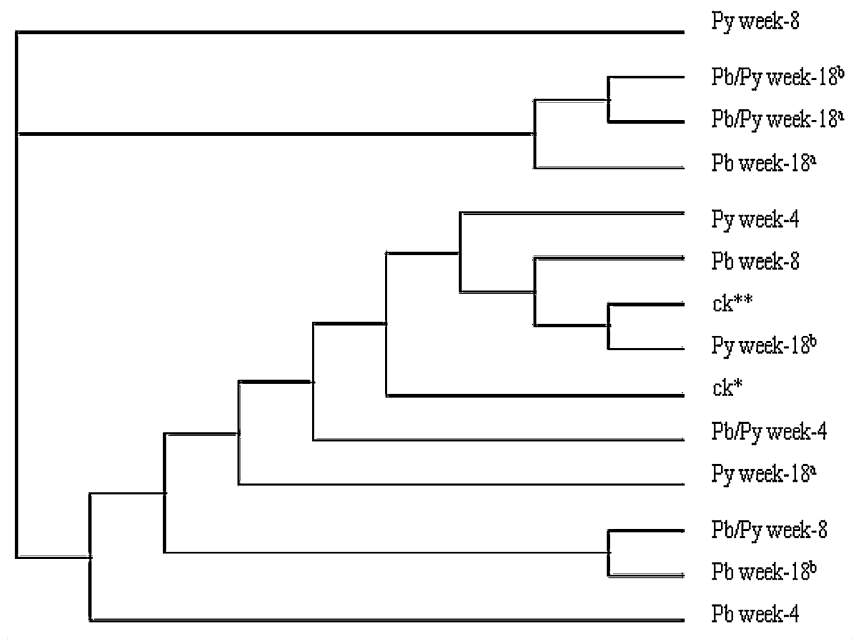

soils as compared with non-rhizospheric soils, particularly for $\mathrm{Pb} /$ pyrene-amended samples. Furthermore, the DGGE profiles indicated that pyrene addition caused a greater change in the soil microbial richness as compared to $\mathrm{Pb}$ and control amendments. As shown in Fig. 2, the majority of bands were less evenly localized, particularly in the $\mathrm{Pb} /$ pyrene-amended samples, while there were a few bands localized in the middle part of the gel. Generally, in the $\mathrm{Pb} /$ pyrene-amended soils, more bands appeared in the lower parts of the gel under higher denaturing conditions. In the amended samples, different pollution scenarios have changed the soil bacterial community structure differently as shown by band patterns of the DGGE.

Similar dendrograms and phylogenetic analysis were generated by the image analysis of DGGE coupled with the Dice similarity coefficient and showed that the DGGE profiles of the amended samples could be well discriminated from the control (see Fig. 2). The DGGE profile showed that similarity decreased between the amended and the control samples with both types of pollutants and incubation period, for both rhizospheric and non-rhizospheric soils. Dendrogram analysis of the DGGE banding patterns confirmed that the addition of $\mathrm{Pb}$ and pyrene had a significant impact on the community structure in both rhizospheric and non-rhizospheric soils.

\subsection{PCR detection of dioxygenase genes}

The presence of nahAc, phnAc, and pdol genes was investigated using a PCR detection method, as shown in Table 2. In the control and $\mathrm{Pb}$-amended soil, pdol and nahAc genes were not detected throughout the incubation period but were detected in the pyrene- and $\mathrm{Pb}$ /pyrene- 
Table 2 A summary of PCR detection of nahAc, phnAc, and $p d o l$ bacterial dioxygenase genes in the examined soil samples ( $n=3$ )

\begin{tabular}{|c|c|c|c|c|c|c|c|c|}
\hline \multirow[t]{2}{*}{ Genes } & \multirow[t]{2}{*}{ Treatments } & \multicolumn{7}{|c|}{ Incubation time (weeks) } \\
\hline & & 0 & 2 & 4 & 6 & 8 & 18 (Rhizosphere) & 18 (Non-rhizosphere) \\
\hline \multirow[t]{4}{*}{ nahac } & Control & ND & ND & ND & ND & ND & ND & ND \\
\hline & $\mathrm{Pb}$ & ND & ND & ND & ND & ND & ND & ND \\
\hline & Pyrene & +++ & +++ & ++ & ++ & + & + & + \\
\hline & $\mathrm{Pb} /$ pyrene & +++ & +++ & +++ & ++ & ++ & ++ & ++ \\
\hline \multirow[t]{4}{*}{ pdol } & Control & ND & ND & ND & ND & ND & ND & ND \\
\hline & $\mathrm{Pb}$ & ND & ND & ND & ND & ND & ND & ND \\
\hline & Pyrene & +++ & +++ & +++ & +++ & +++ & +++ & +++ \\
\hline & $\mathrm{Pb} /$ pyrene & +++ & +++ & +++ & +++ & +++ & +++ & +++ \\
\hline \multirow[t]{4}{*}{$p h n A c$} & Control & ND & ND & ND & ND & ND & ND & ND \\
\hline & $\mathrm{Pb}$ & ND & ND & ND & ND & ND & ND & ND \\
\hline & Pyrene & ND & ND & ND & ND & ND & ND & ND \\
\hline & $\mathrm{Pb} /$ pyrene & ND & ND & ND & ND & ND & ND & ND \\
\hline
\end{tabular}

$N D$ no detection, + number of treatment replicates in which the genes were detected

amended soils. However, phnAc genes were not detected in either amended or non-amended soils throughout the incubation period.

\subsection{Pyrene degraders}

At the beginning of the experiment, pyrene degrader populations were very low and ranged from $0.01 \times 10^{3}$ to
$0.1 \times 10^{3}$ cells $\mathrm{g}^{-1}$ while, during the incubation period, the pyrene degrader populations developed. The number of culturable pyrene degraders was higher in the rhizospheric than in the non-rhizospheric soil. The highest densities were found in week 18 in the rhizospheric soil and week 2 in non-rhizospheric soils (Fig. 3). The addition of pyrene had a dramatic effect on the number of pyrene degraders. In the rhizospheric soils, within 18 weeks, the MPN
Fig. 3 Pyrene degraders in the rye grass rhizospheric and nonrhizospheric soils in different treatments (a) control,

(b) $\mathrm{Pb}$, (c) pyrene, and (d)

$\mathrm{Pb}$ /pyrene mix
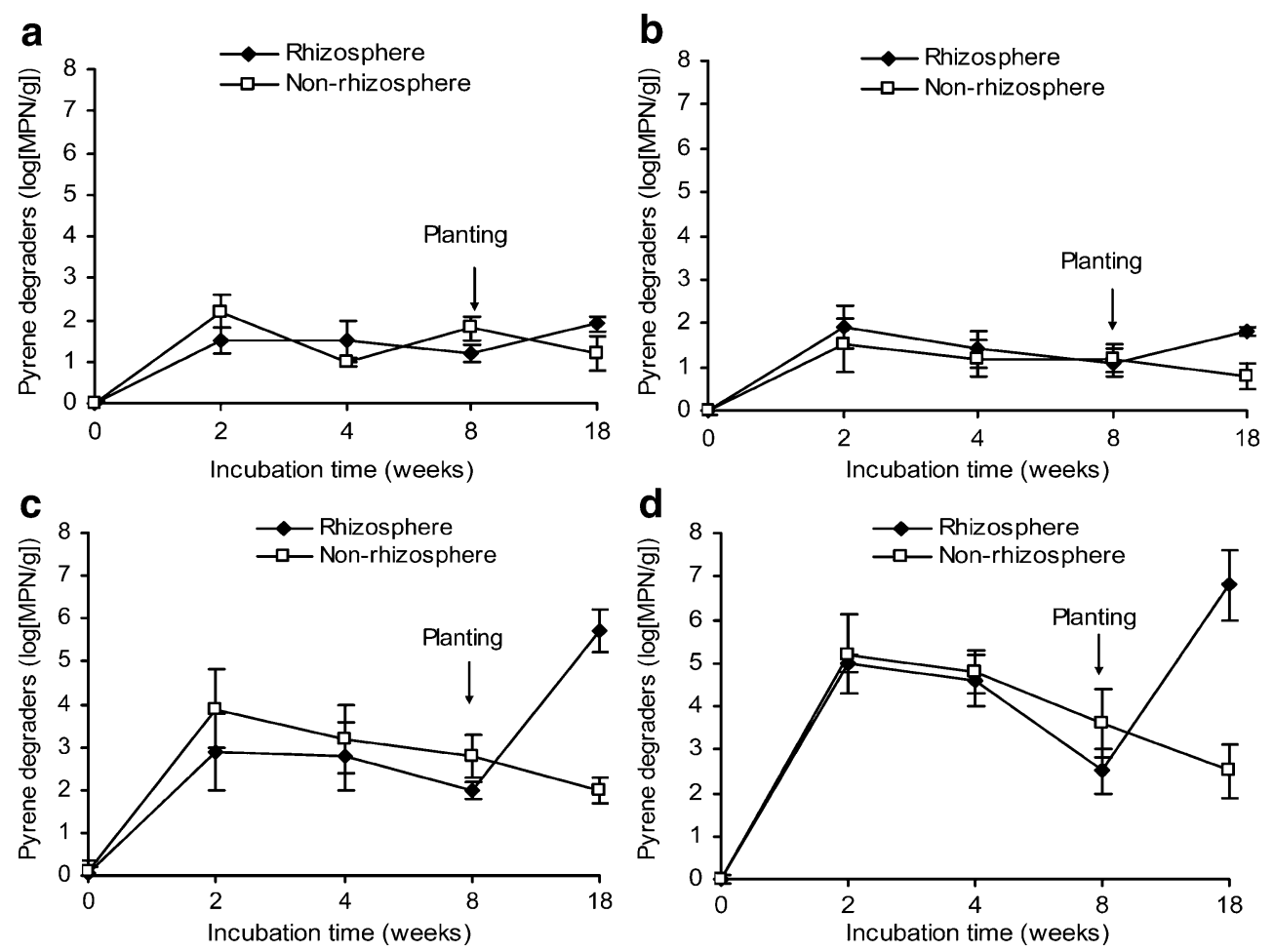
counts rose from $0.03 \times 10^{3}$ cells $\mathrm{g}^{-1}$ to $5.7 \times 10^{3}$ cells $\mathrm{g}^{-1}$ (pyrene-amended soil) and from $0.02 \times 10^{3}$ cells $\mathrm{g}^{-1}$ to $6.8 \times 10^{3}$ cells $\mathrm{g}^{-1}(\mathrm{~Pb} /$ pyrene-amended soil). In nonrhizospheric soils, MPN counts rose from $0.1 \times 10^{3}$ cells $\mathrm{g}^{-1}$ to $3.9 \times 10^{3}$ cells $\mathrm{g}^{-1}$ (pyrene-amended soil) and from $0.01 \times$ $10^{3}$ cells g ${ }^{-1}$ to $5.2 \times 10^{3}$ cells g $^{-1}$ ( $\mathrm{Pb} /$ pyrene-amended soil) within 2 weeks and then decreased during the rest of the incubation period.

\section{Discussion}

\subsection{Pyrene degradation}

Biodegradation is a significant removal mechanism for PAHs in soils and has been intensively studied in recent years (Mueller and Shann 2006; Macleod and Semple 2006; Johnsen et al. 2007). Plants contribute to the degradation of PAHs by increasing the size of microbial population, promoting microbial activity, and modifying microbial community diversity in the rhizosphere (Joner and Leyval 2003). In this study, the presence of plants significantly promoted the degradation of pyrene in the soil due to enhanced bacterial community size and the increased number of pyrene degraders. Similarly, the results of this study have also clearly shown that pyrene remaining in soils only accounted for about $1 / 3$ of the total pyrene addition, suggesting that most of the pyrene added could be removed by plant and/or microbial biodegradation. The present study demonstrated that pyrene degradation was more effective in rhizospheric than in non-rhizospheric soils. These results are in agreement with the findings of previous studies (Joner and Leyval 2003; Arthur et al. 2005). The degradation of pyrene has been shown to increase after the introduction of plants due to enhanced microbial population size and activity (Kamath et al. 2004; $\mathrm{Xu}$ et al. 2006). According to PAH degradation mechanisms through bacteria, the dioxygenase enzymes introduce two atoms of oxygen into pyrene to form a cis-dihydrodiol (Kim et al. 2006).

\subsection{Bacterial community structure}

The DGGE profiles showed that bacterial community structure was changed in all amendments, particularly in pyrene, and $\mathrm{Pb} /$ pyrene amended soils. In this study, rhizospheric soil had a little more complex DGGE pattern, as compared to nonrhizospheric soil, thus indicating the presence of a higher number of different bacterial taxa because each band in the profile represented an individual bacterial species (Luca et al. 2002). Typically, plant roots furnish and constitute easily degradable carbons that generally increase microbial activity in soil, which may ultimately lead to enhance degradation of pyrene through direct metabolism in the rhizosphere (Xu et al. 2006). Root-exudates have various phytochemicals such as linoleic acid helping in the stimulation of pyrene degradation (Yi and Crowley 2007).

\subsection{Interaction of $\mathrm{Pb}$ and pyrene}

The results indicated that the degradation of pyrene was higher in $\mathrm{Pb}$ /pyrene-amended soils as compared with only pyrene-amended soils. It is suggesting that $\mathrm{Pb}$ can be promoting bacterial growth through detoxification of pyrene, which is further accelerating the degradation of PAHs. According to Moreau et al. (1999), the presence of $\mathrm{Zn}$ may result in an increased detoxification of phenanthrene. These findings are also supported in our study. HMs and PAHs interaction toward the degradation of PAHs can be both negative and positive depending on the type and concentration of both the HMs and PAHs. The interactions between HMs and PAHs and their combined effects on a bacterial community are also strongly dependent on the incubation period. However, the interaction between $\mathrm{Pb}$ and pyrene was negative in this study. Shen et al. (2005) also found a negative interaction between $\mathrm{Zn}$ and Benzo $(a)$ pyrene on urease activity, but there is no published report to support the negative interaction between $\mathrm{Pb}$ and pyrene. $\mathrm{Pb}\left(150-300 \mathrm{mg} \mathrm{kg}^{-1}\right)$ has induced influences on microbial communities, which ultimately leads to changes in their activities (Khan et al. 2007). Further intensive research is needed to better understand the mechanisms of interactions present between HMs and PAHs.

\subsection{Functional genes and pyrene degraders}

In this study, the control and $\mathrm{Pb}$-amended soils were scored negatively for $n a h A c$ and $p d o 1$ genes, while phnAc gene was not detected in any amended soils. The nahAc gene is highly conserved among different Gram-negative bacteria, and it has been suggested that natural horizontal gene transfer has occurred between different species that carry this gene (Stuart-Keil et al. 1998). This is supported by the observation that PCR with primers designed from the nahAc gene in P. putida PaW736 (NCIB 9816) can detect not only naphthalene-degrading Pseudomonas species but also strains of Mycobacterium, Gordona, Sphingomonas, Rhodococcus, and Xanthomonas that can degrade HMWPAHs, including fluoranthene and pyrene (Hamann et al. 1999). The prevalence of $n a h A c$ genes in the soils declined during incubation, indicating poor survival of $\mathrm{PAH}$ degraders containing nahAc genes. These results agreed with the findings of a previous study conducted by Johnsen et al. (2006). Recently, phnAc genes were demonstrated in other $\beta$ - and $\gamma$-proteobacteria, low $\mathrm{G}+\mathrm{C}$ Gram-positive bacteria (Widada et al. 2002), and in DNA extracts from 
PAH-contaminated soils (Lloyd-Jones et al. 1999; Laurie and Lloyd-Jones 2000). Similarly, a large percentage of PAH-degrading isolates from diverse geographical locations did not hybridize to the classical nah gene probes (Johnsen et al. 2006). The pdol gene was discovered in Mycobacterium sp. strain 6PY1 (Krivobok et al. 2003), a high G+C Gram-positive genus often associated with degradation of HMW-PAHs in soil (Leys et al. 2005). The pdol genes also facilitate the growth of bacteria on the four-ring PAHs such as pyrene (Krivobok et al. 2003). In our study, the dominant catabolic gene was pdo1, as also found by Johnsen et al. (2006). The dioxygenase encoded by $p d o 1$ was related to PAH dioxygenases from Mycobacteriaceae (Mycobacterium sp. PYR-1, Nocardioides sp. KP7, and the two Rhodococcus sp. I24 and NarAa. NCIMB12038), which form a cluster distinct from other ring-hydroxylating dioxygenases (Khan et al. 2001; Krivobok et al. 2003).

The number of pyrene degraders was drastically changed and significantly higher $(P \leq 0.05)$ in rhizosphere than in non-rhizosphere soils in the 18 -week samples. The size of pyrene-degrading population increased between one to five orders of magnitude in all soil samples. Similarly, this increase in size was between two to seven orders of magnitude within 18 weeks in rhizospheric soils, while it decreased between one to two orders of magnitude at the end of the incubation in non-rhizospheric soils. The decline in the number of pyrene degraders was probably due to substrate limitations because nutritional supplements were not given to the soils.

\section{Conclusions}

Pyrene removal efficiency for rhizospheric soils was significantly $(P<0.05)$ higher than for non-rhizospheric soils. Pyrene dissipation was accelerated in the presence of $\mathrm{Pb}$ in both rhizospheric and non-rhizospheric soils. The bacterial community structure was changed in all amended soils, as demonstrated by the DGGE technique. Moreover, the addition of pyrene indicated a dramatic effect on the number of pyrene degraders, and they were more abundant in the rhizospheric than in the non-rhizospheric soils. The existence of catabolic genes (nahAc and pdol), which are responsible for HMW-PAH degradation, was confirmed in both rhizospheric and non-rhizospheric soils amended with pyrene or $\mathrm{Pb} /$ pyrene, while phnAc was not detected.

Acknowledgments This research was financially supported by Chinese Ministry of Science and Technology (2007CB407301 and 007CB407304), Chinese Academy of Sciences (KZCX1-YW-06-03). We thank Dr. Patrick O'Connor and Ms. Margaret Cargill, the University of Adelaide, Australia, for their critical review of this manuscript.

\section{References}

Arthur EL, Rice PJ, Rice PJ, Anderson TA, Baladi SM, Henderson KLD, Coats JR (2005) Phytoremediation-an overview. Crit Rev Plant Sci 24:109-122

Baldwin BR, Nakatsu CH, Nies L (2003) Detection and enumeration of aromatic oxygenase genes by multiplex and real-time PCR. Appl Environ Microb 69:3350-3358

Brinch UC, Ekelund F, Jacobsen CS (2002) Method for spiking soil samples with organic compounds. Appl Environ Microb 68:1808-1816

Chadhain SMN, Sean Norman R, Pesce KV, Kukor JJ, Zylstra GJ (2006) Microbial dioxygenase gene population shifts during polycyclic aromatic hydrocarbon biodegradation. Appl Environ Microb 72:4078-4087

Hamamura N, Olson SH, Ward DM, Inskeep WP (2006) Microbial population dynamics associated with crude-oil biodegradation in diverse soils. Appl Environ Microb 72:6316-6324

Hamann C, Hegemann J, Hildebrandt A (1999) Detection of polycyclic aromatic hydrocarbon degrading genes in different soil bacteria by polymerase chain reaction and DNA hybridization. FEMS Microbiol Lett 173:255-263

Hatzinger PB, Alexander P (1995) Effect of ageing of chemicals in soil on their biodegradability and extractability. Environ Sci Technol 29:537-545

Hutchinson SL, Schwab AP, Banks HK (2003) Biodegradation of ptroleum hydrocarbons in the rhizosphere. In: McCutcheon SC, Schnoor JL (eds) Phytoremediation: transformation and control of contaminants. Wiley-Interscience, Inc., Hoboken, NJ, pp 355-385

Johnsen AR, Lipthay JR, Sørensen SJ, Ekelund F, Christensen P, Andersen O, Karlson U, Jacobsen CS (2006) Microbial degradation of street dust polycyclic aromatic hydrocarbons in microcosms simulating diffuse pollution of urban soil. Environ Microbiol 8:535-545

Johnsen AR, Schmidt S, Hybholt TK, Henriksen S, Jacobsen CS, Andersen O (2007) Strong impact on the polycyclic aromatic hydrocarbon (PAH)-degrading community of a PAH-polluted soil but marginal effect on PAH degradation when priming with bioremediated soil dominated by mycobacteria. Appl Environ Microbiol 73:1474-1480

Joner EJ, Leyval C (2003) Rhizosphere gradients of polycyclic aromatic hydrocarbon (PAH) dissipation in two industrial soils and the impact of arbuscular Mycorrhiza. Environ Sci Technol 37:2371-2375

Jouanneau Y, Willison JC, Mayer C, Krivobok S, Chevron N, Besombes JL, Blake G (2005) Stimulation of pyrene mineralization in freshwater sediments by bacterial and plant bioaugmentation. Environ Sci Technol 39:5729-5735

Kamath R, Schnoor JL, Alvarez PJJ (2004) Effect of root-derived substrates on the expression of nah-lux genes in pseudomonas fluorescens HK44: implications for PAH biodegradation in the rhizosphere. Environ Sci Technol 38:1740-1745

Kaplan CW, Kitts CL (2004) Bacterial succession in a petroleum land treatment unit. Appl Environ Microbiol 70:1777-1786

Khan AA, Wang RF, Cao WW, Doerge DR, Wennerstrom D, Cerniglia CE (2001) Molecular cloning, nucleotide sequence, and expression of genes encoding a polycyclic aromatic ring dioxygenase from Mycobacterium sp. strain PYR-1. Appl Environ Microbiol 67:3577-3585

Khan S, Cao Q, Chen B, Zhu YG (2006) Humic acids increase the phytoavailability of $\mathrm{Cd}$ and $\mathrm{Pb}$ to wheat plants cultivated in freshly spiked, contaminated soil. J Soils Sediments 6:236242

Khan S, Cao Q, Hesham AB, Xia Y, He J (2007) Soil enzymatic activities and microbial community structure with different application rates of $\mathrm{Cd}$ and $\mathrm{Pb}$. J Environ Sci 19:834-840 
Khan S, Cao Q, Lin AJ, Zhu YG (2008a) Concentrations and bioaccessibility of polycyclic aromatic hydrocarbons in wastewater-irrigated soil using in vitro gastro-intestinal test. Environ Sci Pollut Res 15:344-353

Khan S, Aijun L, Zhang S, Hu Q, Zhu YG (2008b) Accumulation of polycyclic aromatic hydrocarbons and heavy metals in lettuce grown in contaminated soils from long-term wastewater irrigation. J Hazard Mat 152:506-515

Kim SJ, Kweon O, Freeman JP, Jones RC, Adjei MD, Jhoo JW, Edmondson RD, Cerniglia CE (2006) Molecular cloning and expression of genes encoding a novel dioxygenase involved in low- and high-molecular-weight polycyclic aromatic hydrocarbon degradation in Mycobacterium vanbaalenii PYR-1. Appl Environ Microbiol 72:1045-1054

Krivobok S, Kuony S, Meyer C, Louwagie M, Willison JC, Jouanneau Y (2003) Identification of pyrene-induced proteins in Mycobacterium sp strain 6PY1: evidence for two ringhydroxylating dioxygenases. J Bacteriol 185:3828-3841

Laurie AD, Lloyd-Jones G (1999) The phn genes of Burkholderia sp. strain RP007 constitute a divergent gene cluster for polycyclic aromatic hydrocarbon catabolism. J Bacteriol 181:531-540

Laurie AD, Lloyd-Jones G (2000) Quantification of phnAc and nahAc in contaminated New Zealand soils by competitive PCR. Appl Environ Microbiol 66:1814-1817

Leys NMEJ, Bastiaens L, Verstraere W, Springael D (2005) Influence of the carbon/nitrogen/phosphorus ratio on polycyclic aromatic hydrocarbons degradation by Mycobacterium and Sphingomonas in soil. Appl Environ Microbiol 66:726-736

Lloyd-Jones G, Laurie AD, Hunter DWF, Fraser R (1999) Analysis of catabolic genes for naphthalene and phenanthrene degradation in contaminated New Zealand soils. FEMS Microbiol Ecol 29:69-79

Luca C, Daniele A, Marisa M, Comi G (2002) An application of DGGE analysis to profile the yeast population in raw milk. Int Dairy J 12:407-411

Macleod CJA, Semple KT (2006) The influence of single and multiple applications of pyrene on the evolution of pyrene catabolism in soil. Environ Pollut 139:455-460

Moreau CJ, Klerks PL, Haas CN (1999) Interaction between phenanthrene and zinc in their toxicity to the sheepshead minnow (Cyprinodon variegatus). Arch Environ Contam Toxicol 37:251-257

Mueller KE, Shann JR (2006) PAH dissipation in spiked soil: impacts of bioavailability, microbial activity, and trees. Chemosphere 64:10061014

Muyzer G, de EC Waal, Uitterlinden AG (1993) Profiling of complex microbial populations by denaturing gradient gel electrophoresis analysis of polymerase chain reaction-amplified genes coding for 16S rRNA. Appl Environ Microbiol 59:695-700

Rentz JA, Alvarez P, Schnoor JL (2004) Repression of Pseudomonas putida phenanthrene-degrading activity by plant root extracts and exudates. Environ Microbiol 6:574-583

Shen G, Lu Y, Zhou Q, Hong J (2005) Interaction of polycyclic aromatic hydrocarbons and heavy metals on soil enzyme. Chemosphere 61:1175-1182

Shen G, Lu Y, Hong J (2006) Combined effect of heavy metals and polycyclic aromatic hydrocarbons on urease activity in soil. Ecotox Environ Safety 63:474-480

Stapleton RD, Savage DC, Sayler GS, Stacey G (1998) Biodegradation of aromatic hydrocarbons in an extremely acidic environment. Appl Environ Microbiol 64:4180-4184

Stuart-Keil KG, Hohnstock AM, Drees KP, Herrick JB, Madsen EL (1998) Plasmids responsible for horizontal transfer of naphthalene catabolism genes between bacteria at a coal tar-contaminated site are homologous to pDTG1 from Pseudomonas putida NCIB 9816-4. Appl Environ Microbiol 64:3633-3640

$\mathrm{Su}$ YH, Zhu YG (2007) Transport mechanisms for the uptake of organic compounds by rice (Oryza sativa) roots. Environ Pollut 148:94-100

Tang L, Tang XY, Zhu YG, Zheng MH, Miao QL (2005) Contamination of polycyclic aromatic hydrocarbons (PAHs) in urban soils in Beijing, China. Environ Int 31:822-828

US-EPA (2000) Introduction to phytoremediation. US Environmental Protection Agency, Publication No. 600/R-99/107

Widada J, Nojiri H, Kasuga K, Yoshida T, Habe H, Omori T (2002) Molecular detection and diversity of polycyclic aromatic hydrocarbon-degrading bacteria isolated from geographically diverse sites. Appl Environ Microbiol 58:202-209

Wu Y, Luo Y, Zou D, Ni J, Liu W, Teng Y, Li Z (2008) Bioremediation of polycyclic aromatic hydrocarbons contaminated soil with Monilinia sp.: degradation and microbial community analysis. Biodegradation 19:247-257

Xu SY, Chen YX, Wu WX, Wang KX, Lin Q, Liang XQ (2006) Enhanced dissipation of phenanthrene and pyrene in spiked soils by combined plants cultivation. Sci Total Environ 363:206-215

Yi H, Crowley DE (2007) Biostimulation of PAH degradation with plants containing high concentrations of linoleic acid. Environ Sci Technol 41:4382-4388

Yoon J, Cao X, Zhou Q, Ma LM (2006) Accumulation of Pb, Cu, and $\mathrm{Zn}$ in native plants growing on a contaminated Florida site. Sci Total Environ 368:456-464 